\title{
FINANCIAL MARKETS IN OCTOBER 2015
}

\author{
E.Gorbatikov, E.Khudko
}

The MICEX Index in the period between 27 October and 26 November 2015 increased $6.8 \%$ to 1712 points as oil prices fell. Sberbank reported two consecutive months of return on equity higher than other blue chips. The Moscow Exchnage trade turnover and overall capitalization continued to increase. Russia-focused mutual funds again saw investments outflow following a short break in October. The situation in the Russian corporate bond market remained complex driven primarily by domestic factors. The key indicators such as the corporate bond market volume and index and the weighted average yield rate of bond issuances (especially in the energy market segment) saw moderately positive dynamics. Investors and issuers activity remained at the average annual levels. Issuers' defaults on obligations to bondholders remained a problem.

\section{The dynamics of basic structural indices in the Russian stock market}

A new period ${ }^{1}$ was opened by substantial growth in oil prices; the two oil futures hikes on 28 October and 3 November pushed Brent oil up above $\$ 50$ per barrel ${ }^{2}$, reaching the highest value in the period under review. A bit later, however, the price began to fall - below $\$ 44$ by mid-November. The price fell $3.7 \%$ during the month despite some stabilization by the end of the period under review (\$45.58 per barrel as of 26 November). The MICEX Index saw positive dynamics for two consecutive months (October-November). The Index continued to grow in the second half of November despite the fall in oil prices, reaching as high as 1868 points (23 November) during the period under review. The Index gained $6.8 \%$ by the end of November and increased more than $13 \%$ in October-November.

Sberbank's stock price continued to grow. Sberbank was reported to deliver return on equity higher than other blue chips, reaching $19.6 \%$ in November and more than $40 \%$ in October-November. The major hike in quotations ( $7 \%$ daily) was seen on 17 November. Even LUKOIL managed to deliver monthly ROE more than $10 \%$. Norilsk Nickel was the only high liquidity company ${ }^{3}$ whose stock price depreciated during the period under review (down 3.3\%). The rest of the companies saw insignificant growth by the end of the month.

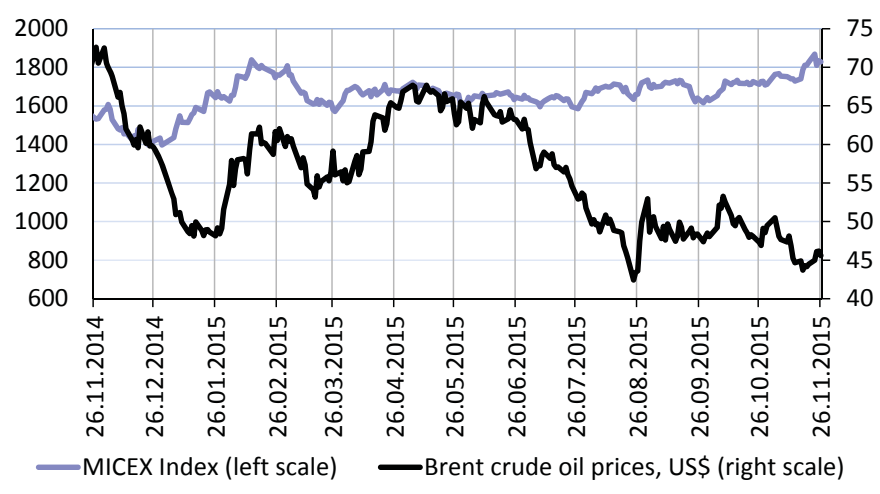

Source: Quote RBC, Finam.

Fig. 1. The dynamics of the MICEX Index and futures prices of Brent crude oil in the period between 26 November 2014 and 26 November 2015

127 October 2015 - 26 November 2015.

2 The data hereinafter refer to the MICEX closing data.

3 High liquidity companies are hereinafter referred to as companies whose average daily trade volume in the period under review was more than $\mathrm{Rb} 1 \mathrm{bn}$. 


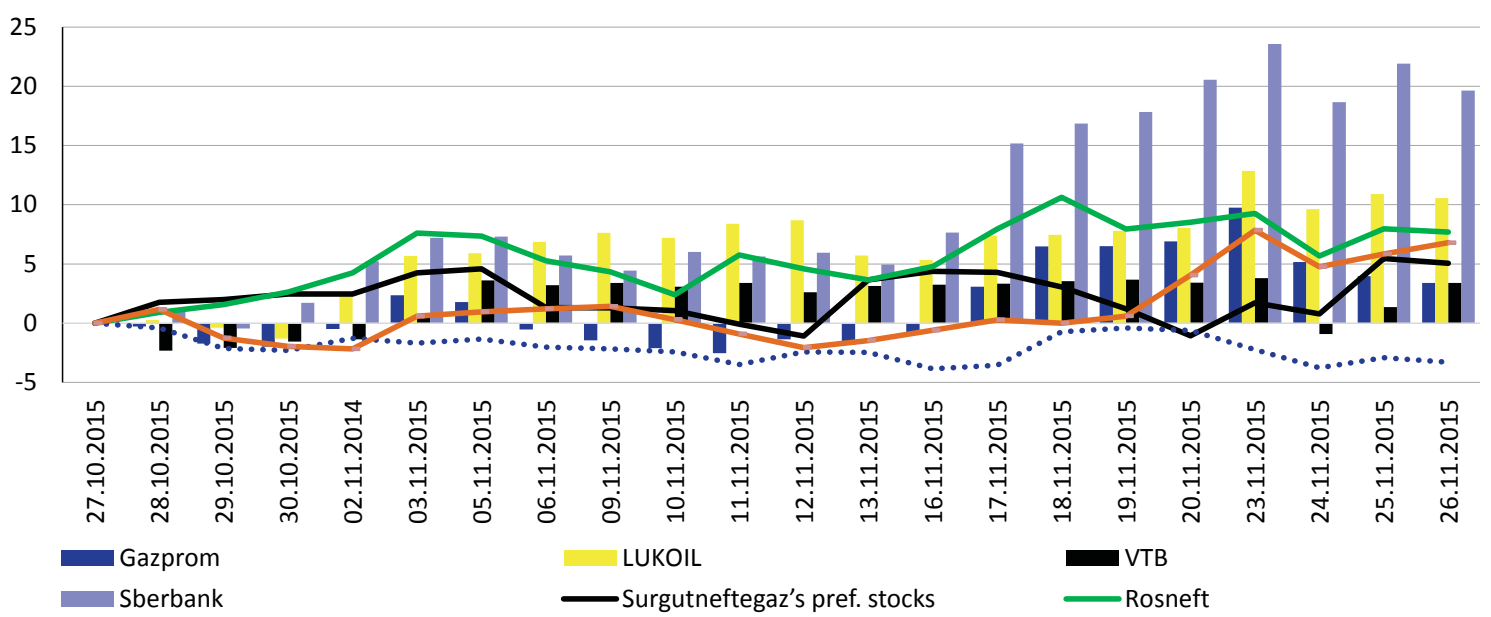

Source: Quote RBC, author's calculations.

Fig. 2. Growth rates in quotations of Russian highly liquid stocks in the Moscow Exchange in the period between 27 October 2015 and 26 November 2015

The top-3 ROE blue chips saw some changed during the period between 27 November 2014 and 26 November 2015. Sberbank was ranked 2nd in annual ROE among the high liquidity companies because its stock price soared (up $44.2 \%$ ) during the past two months. VTB once again was ranked 1st in annual ROE, its stock price was up $61.0 \%$. Surgutneftegaz was ranked 3 rd, up $33.1 \%$. Gazprom was the only high liquidity company whose stock price depreciated (down 1.6\%) at year-end. Norilsk Nickel, which as

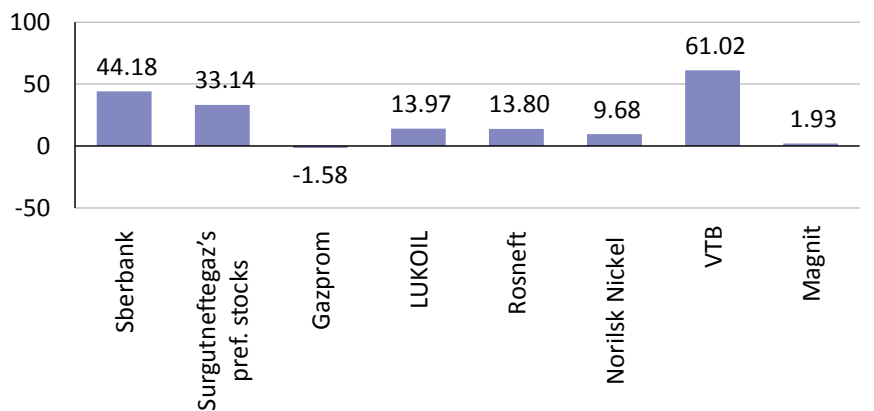

Source: Quote RBC, authors' calculations.

Fig. 3. Growth rates in the value of highly liquid Russian stocks in the Moscow Exchange in the period between 27 November 2014 and 26 November 2015

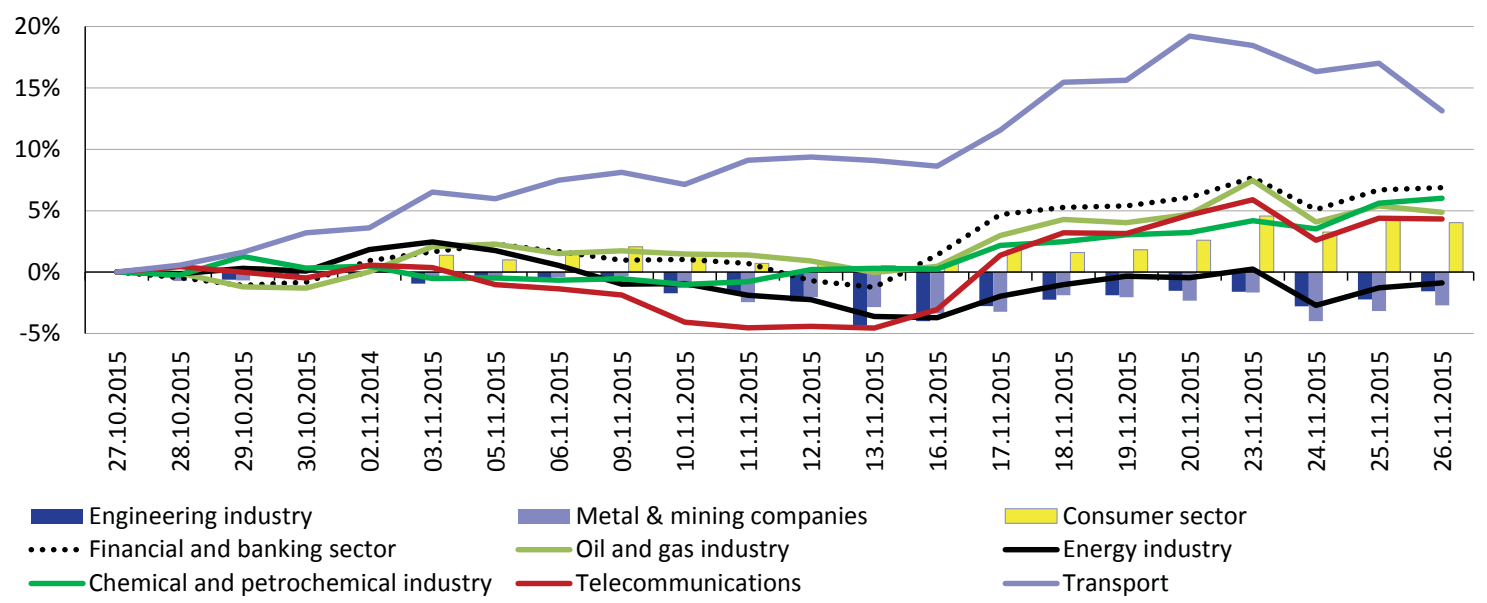

Source: Quote RBC, author's calculations.

Fig. 4. Daily growth rates in various sector stock indices in the Moscow Exchange in the period between 27 October 2015 and 26 November 2015 
early as in October was in the top-3 list, now was behind LUKOIL (up 14.0\%) and Rosneft (up 13.8\%).

Most of the sector indices strengthened for two consecutive months (October-November). The Transport Sector Index saw the fastest growth versus other indices during the month, driven by a more than $16 \%$ hike in Aeroflot's stock price, which accounts for more than a half of the Index. The Finance and Banking Sector Index saw a second highest growth of 6.9\% through a major contribution of Sberbank. The Chemical and Oil \& Gas Sector Indices, the Telecommunications and Consumer Sector Indices increased $4-6 \%$. The rest of the indices saw an insignificant decline, whereas the Metal and Mining Sector Index dropped deeper than others (down 2.7\%).

The Moscow Exchange's (MOEX) turnover continued to increase. The total monthly MOEX total turnover increased for the first time in a long period increased to more than $\mathrm{Rb} 800 \mathrm{bn}$, being equal to a daily average of $\mathrm{Rb} 36.4 \mathrm{bn}$ and almost equal to the daily turnover of the same period last year. The difference between November and October is $4 \%$, more than $8 \%$ above the quarterly average.

Sberbank saw its stock price grow as its share of the MOEX overall turnover increased to $34.3 \%$ during the period under review (27 October 26 November 2015) - Sberbank's common and preferred stocks were involved in more than one of three MOEX transactions. Gazprom's share increased more than $1 \%$ to $14.8 \%$ (against $13.4 \%$ in the previous month). By contrast, LUKOIL lost $8.0 \%$ of its share in November (against $9.6 \%$ in the previous month). Another five companies showed more than $\mathrm{Rb} 1 \mathrm{bn}$ of the MOEX average daily turnover, namely Norilsk Nickel, Magnit, Surgutneftegaz, Rosneft and VTB. Note that MTS companies saw substantial growth in the average market turnover (more than $50 \%$ of the previous period market turnover). The top-3 leaders accounted for $57.1 \%$ of the total market share (an increase of $2 \%$ over the previous month). The next five companies accounted for $21.5 \%$ of the total market turnover.

According to the Emerging Portfolio Fund Research (EPFR), the first three weeks of November saw investment outflow from Russia-focused mutual funds, which were worth a total of $\$ 164.4 \mathrm{~m}$ in the period between 29 October and 18 November. Despite the inflow of $\$ 104.6 \mathrm{~m}$ during the last week of

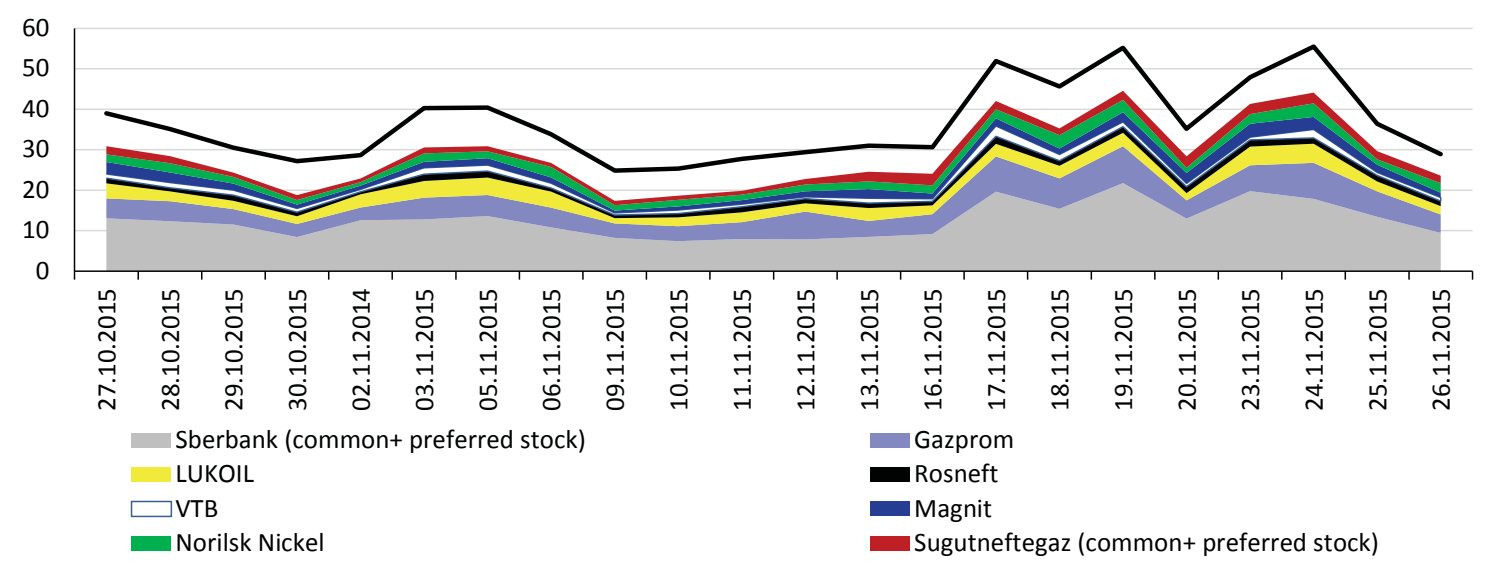

Source: RBK Quote, author's calculations.

Fig. 5. The structure of Moscow Exchange trading volumes in the period between 27 October 2015 and 26 November 2015 
November (19-25 November), monthly outflows were worth more than $\$ 1 \mathrm{bn}$ both at month-end and year-end 2015.

The MICEX capitalization as of 26 November 2015 was more than $\mathrm{Rb} 30$ trillion ( $\mathrm{Rb} 30.28$ trillion or $42.4 \%$ of GDP), higher by $5 \%$ over the amount reported during the previous period under review. The financial sector's share of the MICEX capitalization structure continued to increase, up $0.6 \%$ in the past month. The metal \& mining industry lost $1.1 \%$, whereas other industries saw insignificant changes in their share of MICEX capitalization.

\section{Corporate bond market}

The volume of Russia's domestic corporate bond market (measured by the par value of outstanding rouble-denominated securities including those issued by non-residents) in November kept growing at a slow pace. By the end of the month the volume hit a new all-time highest, reaching $\mathrm{Rb} 7781.6 \mathrm{bn}$, higher by $0.9 \%$ over the value seen as of the end of October ${ }^{1}$. The elapsed period saw some increase in the number of outstanding bond issuances (1172 corporate bond issuances denominated in national currency were registered versus 1167 issuances as of the end of October), whereas the number of issuers in the debt segment reduced (390 issuers against 399 companies in the previous month). Eighteen dollar-denominated bonds issuances of Russian companies (worth a total of more than $\$ 4.8 \mathrm{bn}$ ) and one JPYdenominated bond issuance (it is worth noting, however, that the issuer has entered into liquidation) remained outstanding in the market.

Investors' activity in the secondary corporate bond market in November increased following a period of relative stabilization. For instance, in the period between 24 October 2015 and 23 November 2015, the MOEX total trading volume in securities denominated in the national currency amounted to $\mathrm{Rb} 142.4 \mathrm{bn}$ (by contrast, the trading volume in the period between 25 eptember 2015 and 23 October 2015 was equal to Rb 122.1bn). Furthermore, 32,600 MOEX transactions were closed during the period under review; it is still a high-level number despite being smaller than a record in October (by contrast, 34,400 MOEX transactions were closed in the previous period) ${ }^{2}$.

The Russian Corporate Bond Market Index (IFX-Cbonds) in November continued to grow at a steady pace. At the end of the month, the index increased 4.3 points (or $1.0 \%$ ) over the value seen at the previous month's end. The average weighted yield of corporate bonds in October continued to decline as in September, with a minimum pace though. As a result, the value dropped from $11.66 \%$ late in October to $11.56 \%$ by the end of November (Fig. 7$)^{3}$. The value is still higher by 0.5 p.p. over the central bank base rate of interest.

1 According to the data supplied by Rusbonds Information Agency.

2 According to the data supplied by Finam Investment Company.

3 According to the data supplied by Cbonds Information Agency. 
However, the corporate bond portfolio duration saw negative dynamics for last eight months, which was 282 days as of the end of November, which is by 29 days less than the value seen as of the end of previous month.

The Russian market in November was driven primarily by domestic market news. First of all, higher inflation risks interfere with the Russian central bank policy of cutting the base rate of interest which in turn serves as a guidance in the dynamics of corporate bond yields. The nega-

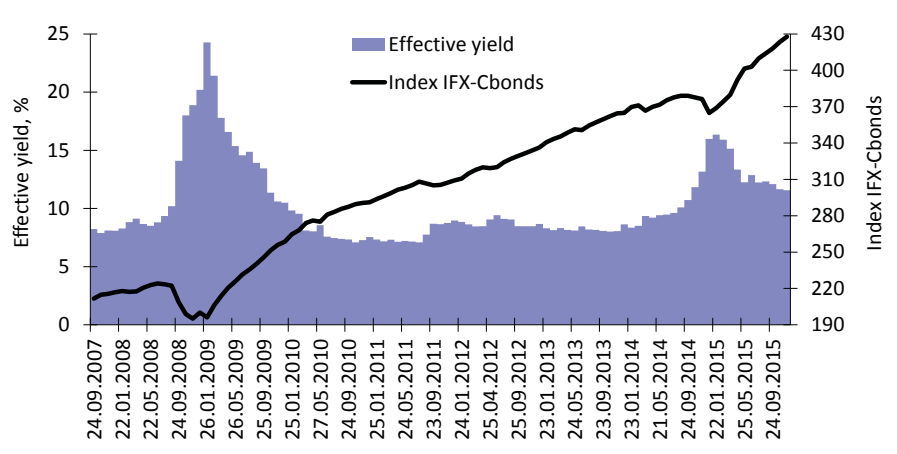

Source: According to the data provided by Cbonds Information Agency .

Fig. 7. The dynamics of the Russian corporate bond market index and average weighted yield tive dynamics of GDP, industrial production, fixed investment volumes continued. Additionally, the period under review covers companies' financial statements for 9 M 2015, which brought no optimism to investors. Some regional energy operators and large financial and production companies showed negative dynamics in terms of financial performance.

International rating agencies' forecast for Russian issuers was predictable in general: the credit rating of most of Russia's large production and financial companies remained unchanged, namely Gazprombank, MTS-Bank, Roseurobank, Tinkoff Bank, Absolut Bank, Russian Helicopters, Mosenergo, etc., whereas the outlook for some issuers was even upgraded (in particular, Bashneft, Sovcomflot). The Russia sovereign credit rating remained unchanged too, although the outlook by international rating agencies is negative $^{1}$.

The dynamics of securities in the most liquid segment of the domestic corporate bond market differed a lot during the period under review. Securities in the financial and industrial market segments again were highly volatile in terms of dynamics. For instance, bond issuances of PAO VTB Bank (PSJC), PAO Gazprom Neft )(PSJC) and OAO Federal Grid Company of Unified Energy System (OJSC) showed the deepest fall in the interest rate (more than 1 p.p.). At the same time, OAO Russian Railways (series 12) and AO Russian Agricultural Bank (OJSC) (series 11) showed a similar growth in the yield. Liquid securities in the energy market segment saw most marked downward interest rate dynamics (an average decrease of 0.3 p.p.). The yield of bond issuances in the financial and technological segments was not highly volatile, whereas the rates on production companies' securities saw some increase (up by an average of almost 0.2 p.p.) $)^{2}$. Securities of financial and production companies, especially the bonds of PAO BINBANK and OOO EvrazHonding Finance, were in higher investment demand.

Issuers' activity in terms of seeking new fundraising during the period under review decreased slightly while remaining at the average annual level. For instance, in the period between 24 October 2015 and 23 November 201513 issuers registered 15 bond issuances with an aggregate par value

1 According to the data supplied by Finam and Cbonds Information Agencies.

2 According to the data supplied by Finam Investment Company. 
of $\mathrm{Rb} 76.8 \mathrm{bn}$ (by contrast, 24 bond issuances with an aggregate par value of $\mathrm{Rb} 106.0 \mathrm{bn}$ and a single issuance of $\$ 1.75 \mathrm{bn}$ were registered in the period between 25 September 2015 and 23 October 2015) $)^{1}$. Four issuers - OAO Sberbank of Russia, PAO Magnit, OOO Rossium Concern and PAO Second Wholesale Power Market Generating Company ${ }^{2}$ accounted for the biggest volume of bond issuances. A few other major bond programs are expected to register soon; in particular, Rostelecom approved two exchange-traded bonds programs worth $\mathrm{Rb} 300 \mathrm{bn}$,

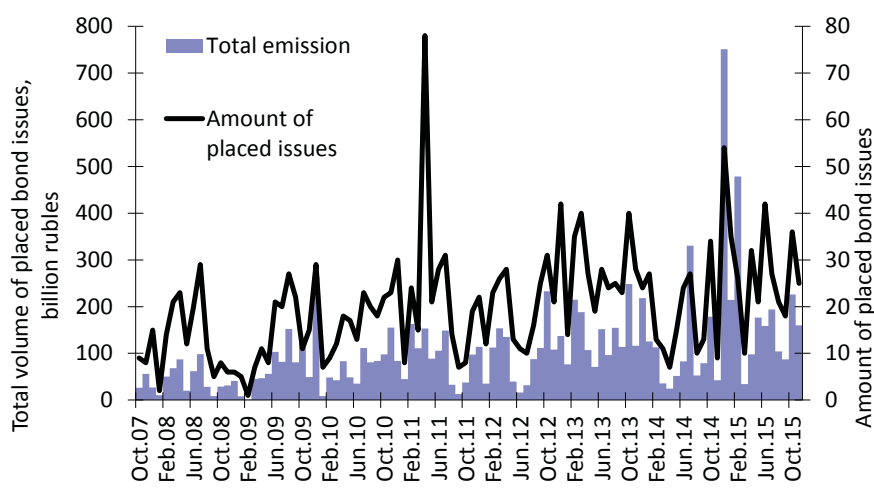

Source: According to the data provided by Rusbonds information agency.

Fig. 8. The dynamics of initial public offerings of corporate bonds denominated in the national currency

Phosagro also approved an exchange-traded bonds program worth $\mathrm{Rb} 50 \mathrm{bn}$.

Investors' activity in the primary market decreased too, remaining, however, at the average annual levels. For instance, in the period between 24 October 2015 and 23 November 2015, 20 issuers placed 25 bond issuances at a total of $\mathrm{Rb} 159.8 \mathrm{bn}$ (by contrast, 36 bond issuances with an aggregate par value of $\mathrm{Rb} 226.0 \mathrm{bn}$ were placed in the period between 25 September 2015 and 23 October 2015) (Fig. 8). The largest bond issuances were placed by OAO SMP Bank (OJSC), OAO Sberbank of Russia (OJSC) and OAO Russian Railways (OJSC) ${ }^{3}$. Most of the bonds placed in the period under review were exchange-traded bonds. Note that in November some companies began to place major bond issuances by private subscription which is still in progress (in particular, the issuances were placed by Russian Railways, YAMAL LNG whose bonds are supposed to be purchased at the expense of the National Welfare Fund). No bond issuances with long maturity were placed during the period under review, however more than a half of issuers managed to raise funds with a maturity of 10 years.

None of the corporate bond issuances in November was cancelled by the Bank of Russia on the ground that not a single bond has been issued (a few corporate bond issuances were cancelled on the same ground in each of the previous few months, because issuers changed their fundraising strategy due to poor market conditions) $)^{4}$.

In the period between 24 September 2015 and 23 November 2015, 16 bond issuers were to redeem 22 bond issuances with a aggregate par value of $\mathrm{Rb} 108.1 \mathrm{bn}$. However, a single issuer failed to meet its obligations in due time and announced a technical default on two bond issuances worth a total of $\mathrm{Rb} 3 \mathrm{bn}$ (no technical defaults took place in the previous period). Twenty corporate bond issuances worth a total of $\mathrm{Rb} 89.9 \mathrm{bn}$ are due to mature in December $2015^{5}$.

1 According to the data supplied by Rusbonds Information Agency.

2 According to the data supplied by Rusbonds Information Agency.

3 According to the data supplied by Rusbonds Information Agency.

4 According to the data supplied by the Bank of Russia.

5 According to the data provided by Rusbonds Information Agency. 
Overall, issuers' failure to meet obligations to bondholders was still a problem. Utair Finance (Limited Liability Company) and Russia's second-largest airline, Transareo declared actual defaults (that is, a bond issuer is unable to repay to bondholders even during the grace period) on various types of commitments in addition to a few technical defaults, failing to redeem bonds on put date and a few coupon payments (a few technical and actual defaults on coupon yield payment and on put date were announced in the same period last month) ${ }^{1}$.

1 According to the data provided by Rusbonds Information Agency. 